\title{
Laminar Distribution of Neurochemically-Identified Interneurons and Cellular Co-expression of Molecular Markers in Epileptic Human Cortex
}

\author{
Qiyu Zhu ${ }^{2} \cdot$ Wei Ke ${ }^{1} \cdot$ Quansheng He $^{1} \cdot$ Xiongfei Wang ${ }^{3} \cdot$ Rui Zheng $^{1} \cdot$ \\ Tianfu $\mathrm{Li}^{3} \cdot$ Guoming Luan ${ }^{3} \cdot$ Yue-Sheng Long ${ }^{4} \cdot$ Wei-Ping Liao ${ }^{4}$ (D) \\ Yousheng Shu ${ }^{1}$ (D)
}

Received: 23 January 2018/ Accepted: 20 May 2018/Published online: 31 August 2018

(C) The Author(s) 2018

\begin{abstract}
Inhibitory GABAergic interneurons are fundamental elements of cortical circuits and play critical roles in shaping network activity. Dysfunction of interneurons can lead to various brain disorders, including epilepsy, schizophrenia, and anxiety. Based on the electrophysiological properties, cell morphology, and molecular identity, interneurons could be classified into various subgroups. In this study, we investigated the density and laminar distribution of different interneuron types and the coexpression of molecular markers in epileptic human cortex. We found that parvalbumin (PV) and somatostatin (SST) neurons were distributed in all cortical layers except layer I, while tyrosine hydroxylase $(\mathrm{TH})$ and neuropeptide $\mathrm{Y}$ (NPY) were abundant in the deep layers and white matter. Cholecystokinin (CCK) neurons showed a high density in
\end{abstract}

Electronic supplementary material The online version of this article (https://doi.org/10.1007/s12264-018-0275-x) contains supplementary material, which is available to authorized users.

Yousheng Shu

yousheng@bnu.edu.cn

$1 \quad$ State Key Laboratory of Cognitive Neuroscience and Learning and IDG/McGovern Institute for Brain Research, Beijing Normal University, Beijing 100875, China

2 College of Pharmaceutical Sciences, Brain Institute, Capital Medical University, Beijing 100069, China

3 Department of Neurosurgery, Epilepsy Center, Sanbo Brain Hospital of Capital Medical University, Beijing Key Laboratory of Epilepsy, Epilepsy Institution, Beijing Institute for Brain Disorders, Beijing 100093, China

4 Institute of Neuroscience and Department of Neurology of the Second Affiliated Hospital of Guangzhou Medical

University, Key Laboratory of Neurogenetics and Channelopathies of Guangdong Province and the Ministry of Education of China, Guangzhou 501260, China layers IV and VI. Neurons with these markers constituted $\sim 7.2 \%$ (PV), $2.6 \%$ (SST), $0.5 \%$ (TH), $0.5 \%$ (NPY), and $4.4 \%$ (CCK) of the gray-matter neuron population. Doubleand triple-labeling revealed that NPY neurons were also SST-immunoreactive $(97.7 \%)$, and TH neurons were more likely to express SST (34.2\%) than PV (14.6\%). A subpopulation of CCK neurons (28.0\%) also expressed PV, but none contained SST. Together, these results revealed the density and distribution patterns of different interneuron populations and the overlap between molecular markers in epileptic human cortex.

Keywords Interneuron - Epilepsy $\cdot$ Human cortex $\cdot$ Cell type - Immunostaining - Parvalbumin - Somatostatin . Tyrosine hydroxylase $\cdot$ Neuropeptide Y $\cdot$ Cholecystokinin

\section{Introduction}

In the cerebral cortex, non-pyramidal GABAergic interneurons are involved in cortical information-processing and high-order cognitive functions. Though non-pyramidal cells $(20 \%-30 \%)$ are much less numerous than the main output neurons, pyramidal cells $(70 \%-80 \%)$ [1-3], in the whole population of cortical neurons, they are more extensive and complex. Interneurons can be classified depending on their morphology, intrinsic membrane properties, and synaptic connectivity and dynamics. Distinct interneuron subtypes can be also identified by the expression of specific molecular markers, such as parvalbumin (PV), somatostatin (SST), tyrosine hydroxylase (TH), vasoactive intestinal polypeptide, ionotropic serotonin 5-hydroxytryptamine 3a receptor, nitric oxide synthase, cholecystokinin (CCK), and neuropeptide Y (NPY) [4-6]. Although some of them (e.g. CCK) are also expressed by a 
subpopulation of glutamatergic pyramidal cells [7], neurons labeled with these markers are most likely to be GABAergic cells in the neocortex [5, 8, 9] and possess distinct electrophysiological and morphological features. For example, PV-expressing neurons show a fast-spiking firing pattern and send axons to innervate the perisomatic regions of pyramidal cells, while SST-containing neurons show a low-threshold spiking firing pattern and innervate the distal apical dendrites of pyramidal cells [10-13]. Because of the fundamental role of GABAergic interneuron in providing inhibitory control of cortical network, changes in interneuron circuitry and alterations of GABAergic transmission in the cortex can lead to disorders of cognition and emotion, such as schizophrenia, anxiety, and epilepsy [14-17].

An epileptic seizure is a paroxysmal alteration of function caused by excessive, hyper-synchronous discharge of neurons and abnormal network activity in the brain. Although numerous pathogenic conditions can result in epilepsy along with brain dysfunction [14, 18, 19], its pathophysiology is generally considered to be a distortion of the normal, well-balanced excitation (E) and inhibition (I) in the brain [20]. A genetic or acquired E-I imbalance can result from changes at many levels, from genes and subcellular signaling cascades to neural circuits. GABAergic interneurons are critical circuit elements in the cortex, providing inhibition in cortical networks, and thus contribute significantly to the E-I balance. Alterations in their distribution and density in the cortex, as well as changes in the co-localization of different molecular markers in interneuron subtypes may reflect the mechanisms underlying brain diseases. Previous studies have revealed an association between hippocampal GABAergic interneurons and the generation of epilepsy [21]. Changes in GABA production or GABA receptor expression have been found in epileptic tissues [22, 23]. However, the distribution and co-localization patterns of different molecular markers for GABAergic interneurons in the human epileptic cortex need to be further explored.

Among cortical interneurons, PV- and SST-expressing cells are the most abundant cell types [5, 24]. In the human cortex, PV neurons including chandelier cells and large basket cells [25] comprise $\sim 20 \%$ of all GABAergic neurons [26]; SST neurons are distributed unevenly across the human cortex $[25,27,28]$. PV and SST neurons play important roles in the generation of cortical network activity, such as gamma and beta oscillations [29-31], as well as seizure-like activity [32]. NPY is a neuropeptide produced by certain types of neurons throughout the brain and by secretory cells of other systems [33, 34]. In the neocortex, NPY is expressed in a subpopulation of GABAergic neurons and is involved in brain disorders including seizure activities [33, 35]. The NPY neuron density is high in layers II, III, and VI, and in the white matter of human cortex [36]. TH is a molecular marker of midbrain dopaminergic neurons and is the rate-limiting enzyme of dopamine synthesis. Some cortical cells also express this enzyme and may reflect a unique cell type in the neocortex [37]. TH neurons in the human cortex are mainly located in deep layers and are fusiform, bipolar, or multipolar [38, 39]. Early immunostaining experiments revealed the expression of $\mathrm{CCK}$ in a subpopulation of GABAergic neurons in the neocortex [40]. Some of the CCK-expressing neurons in the hippocampus are basket cells targeting the perisomatic regions of pyramidal cells [41, 42]. Selective loss of hippocampal CCK-containing boutons and thus a decrease in GABA release may cause epilepsy in an animal model of temporal lobe epilepsy $[40,43]$. CCK neurons in the human cortex are also positive for calretinin or reelin [7]. Since a particular cell type may express a combination of markers, it is of interest to determine whether PV and SST cells also express NPY, $\mathrm{TH}$, and CCK, and determine whether cells positive for one of these markers are a subpopulation of PV or SST cells.

In this immunohistochemical study, we performed double- and triple-labeling to analyze the distribution patterns of the above molecular markers of interneurons and their co-localization in cortex from patients.

\section{Materials and Methods}

We used epileptic tissues removed from 9 patients during brain surgery. All were associated with secondary epilepsy caused by various pathological conditions. The cortical areas removed were mainly from the frontal or temporal lobe (Table 1). Non-epileptic peri-tumor tissues were obtained from 3 patients (frontal, temporal, or parietal lobe). The Ethics Committee of Beijing Sanbo Hospital, Capital Medical University, China approved all studies. We have complied with all relevant ethical regulations relating to the use of resected human brain tissue in research. The clinical investigations were conducted according to the Declaration of Helsinki. Informed consent was given by all participants or their parents or legal guardians.

Cortical tissues were removed during the course of neurosurgery for the treatment of patients with intractable epilepsy. Before the surgery, epileptogenic regions were identified by video-EEG recording and the removed regions were associated with significant abnormal spiking. Since we sought to explore the laminar distribution patterns of interneuron subtypes, we chose parts of the removed tissue blocks showing complete cortical layers (from layer I to white matter). All tissues were immersed in $3 \%$ paraformaldehyde (PFA) and $3 \%$ sucrose in $0.1 \mathrm{~mol} / \mathrm{L}$ 
Table 1 Patient information

\begin{tabular}{|c|c|c|c|c|c|c|c|c|}
\hline No. & $\begin{array}{l}\text { Age, } \\
\text { sex }\end{array}$ & $\begin{array}{l}\text { Duration of } \\
\text { epilepsy }\end{array}$ & Etiology & $\begin{array}{l}\text { Seizure } \\
\text { frequency }\end{array}$ & $\begin{array}{l}\text { Previous } \\
\text { treatment }\end{array}$ & Drug treatment & $\begin{array}{l}\text { Surgical } \\
\text { results }\end{array}$ & $\begin{array}{l}\text { Surgical resection } \\
\text { area }\end{array}$ \\
\hline 1 & $\begin{array}{c}16 \mathrm{~m}, \\
\mathrm{~F}\end{array}$ & $7 \mathrm{~m}$ & FCD $2 \mathrm{a}$ & $\begin{array}{l}\text { Several } \\
\text { times/d }\end{array}$ & VNS & $\begin{array}{l}\text { Oxcarbazepine, Sodium val- } \\
\text { proate, Clonazepam }\end{array}$ & $\begin{array}{l}\text { Seizure- } \\
\text { free }\end{array}$ & $\begin{array}{l}\text { Right temporal } \\
\text { lobe }\end{array}$ \\
\hline 2 & $\begin{array}{c}19 \mathrm{~m}, \\
\mathrm{M}\end{array}$ & $12 \mathrm{~m}$ & $\begin{array}{l}\text { Sturge-Weber } \\
\text { syndrome }\end{array}$ & $2-4 / \mathrm{m}$ & None & $\begin{array}{l}\text { Oxcarbazepine, Topiramate, } \\
\text { Clonazepam }\end{array}$ & $\begin{array}{l}\text { Seizure- } \\
\text { free }\end{array}$ & $\begin{array}{l}\text { Left anterior } \\
\text { temporal lobe }\end{array}$ \\
\hline 3 & $\begin{array}{c}14 \mathrm{y} \\
\mathrm{M}\end{array}$ & $14 \mathrm{y}$ & Trauma & $3 / \mathrm{m}$ & None & Sodium valproate & $\begin{array}{l}\text { Seizure } \\
\text { decrease }\end{array}$ & Left frontal lobe \\
\hline 4 & $\begin{array}{c}16 y \\
F\end{array}$ & $6 y$ & FCD $1 b$ & $10 / \mathrm{m}$ & IEI & $\begin{array}{l}\text { Carbamazepine, Sodium } \\
\text { valproate }\end{array}$ & $\begin{array}{l}\text { Seizure- } \\
\text { free }\end{array}$ & $\begin{array}{l}\text { Left anterior } \\
\text { temporal lobe }\end{array}$ \\
\hline 5 & $\begin{array}{c}39 \mathrm{y} \\
\mathrm{M}\end{array}$ & $30 \mathrm{y}$ & FCD $2 b$ & $4-5 / w$ & None & Sodium valproate & No record & Right frontal lobe \\
\hline 6 & $\begin{array}{c}28 \mathrm{y} \\
\mathrm{M}\end{array}$ & $9 \mathrm{y}$ & FCD $1 b$ & $2 / \mathrm{m}$ & IEI & $\begin{array}{l}\text { Oxcarbazepine, Sodium } \\
\text { valproate }\end{array}$ & No record & $\begin{array}{l}\text { Left anterior } \\
\text { temporal lobe }\end{array}$ \\
\hline 7 & $\begin{array}{c}28 \mathrm{y} \\
\mathrm{M}\end{array}$ & $20 \mathrm{y}$ & FCD $1 b$ & $\begin{array}{l}\text { Several } \\
\text { times/d }\end{array}$ & None & $\begin{array}{l}\text { Carbamazepine, Sodium } \\
\text { valproate }\end{array}$ & $\begin{array}{l}\text { Seizure- } \\
\text { free }\end{array}$ & $\begin{array}{l}\text { Left temporal } \\
\text { lobe }\end{array}$ \\
\hline 8 & $\begin{array}{r}8 \mathrm{y} \\
\mathrm{M}\end{array}$ & $8 \mathrm{y}$ & FCD $1 b$ & $10 / w$ & IEI & Oxcarbazepine, Clonazepam & $\begin{array}{l}\text { Seizure } \\
\text { decrease }\end{array}$ & $\begin{array}{l}\text { Left anterior } \\
\text { temporal lobe }\end{array}$ \\
\hline 9 & $\begin{array}{r}8 \mathrm{y}, \\
\mathrm{M}\end{array}$ & $0.5 \mathrm{y}$ & FCD $1 b$ & $3-4 / w$ & None & None & No record & $\begin{array}{l}\text { Left anterior } \\
\text { temporal lobe }\end{array}$ \\
\hline 10 & $\begin{array}{l}62 \mathrm{y} \\
\mathrm{F}\end{array}$ & - & Meningioma & - & - & - & - & Right frontal lobe \\
\hline 11 & $\begin{array}{c}47 \mathrm{y} \\
\mathrm{M}\end{array}$ & - & Melanoma & - & - & - & - & Left parietal lobe \\
\hline 12 & $\begin{array}{l}62 \mathrm{y} \\
\mathrm{F}\end{array}$ & - & Breast cancer & - & - & - & - & $\begin{array}{l}\text { Left temporal } \\
\text { lobe }\end{array}$ \\
\hline
\end{tabular}

m, month; y, year; d, day; w, week; F, female; M, male; focal cortical dysplasia; FCD 1b, defective horizontal lamination with lamina-specific neuronal paucity [44]; FCD 2b, dysplastic megalocytic neurons, balloon cells, delaminated cortical architecture and abnormal glial cells, mixed with neurons and glia that appear histologically normal [44]; IEI, intracranial electrode implantation; Sturge-Weber syndrome, neurocutaneous disorder with angiomas that involve the leptomeninges; VNS, vagus nerve stimulation.

phosphate buffer (PB, $80 \mathrm{mmol} / \mathrm{L} \mathrm{Na}_{2} \mathrm{HPO}_{4}, 16 \mathrm{mmol} / \mathrm{L}$ $\mathrm{NaH}_{2} \mathrm{PO}_{4}, \mathrm{pH} 7.4$ ) at $4{ }^{\circ} \mathrm{C}$ for $2 \mathrm{~h}$. They were then stored in $30 \%$ sucrose in $\mathrm{PB}$ overnight at $4{ }^{\circ} \mathrm{C}$ for cryoprotection. Tissues were cut into $30-\mu \mathrm{m}$-thick sections on a freezing microtome at $-20{ }^{\circ} \mathrm{C}$. Sucrose and residual PFA were washed out in $0.01 \mathrm{~mol} / \mathrm{L}$ PBS buffer (in $\mathrm{mmol} / \mathrm{L}$ : 8 $\mathrm{Na}_{2} \mathrm{HPO}_{4}, 1.6 \mathrm{NaH}_{2} \mathrm{PO}_{4}$, and $145 \mathrm{NaCl}$ ), the sections were then pre-incubated in $0.5 \%$ Triton $\mathrm{X}-100$ in $\mathrm{PB}$ for $30 \mathrm{~min}$, and blocked in 5\% bovine serum albumin and $0.5 \%$ Triton $\mathrm{X}-100$ in $\mathrm{PB}$ for $1 \mathrm{~h}$ at room temperature $\left(22^{\circ} \mathrm{C}\right)$. Sections were then incubated overnight at $4{ }^{\circ} \mathrm{C}$ and two more hours at room temperature in $0.1 \%$ Triton X-100 containing primary antibodies (Supplementary Table S1). After washing with $0.01 \mathrm{~mol} / \mathrm{L} \mathrm{PBS}$, sections were incubated for $2 \mathrm{~h}$ at room temperature in $0.1 \%$ Triton $\mathrm{X}-100$ containing secondary antibodies.

We chose to image non-successive sections ( $\sim 2 \mathrm{~mm} \times$ $2 \mathrm{~mm}$ ) for each experiment so that no cell on the surface would be over-counted. We collected images from 3 regions of interest in separate cortical sections from each patient. The regions of interest for cell counting contained complete cortical layers (from pia to white matter) and at least $1000 \mathrm{NeuN}$-stained cells. For the co-localization of cell markers (double- and triple-staining), we selected regions of similar size but without NeuN staining. Images were captured on a laser scanning confocal microscope (A1+, Nikon, Japan) with $10 \times$ and $20 \times$ objectives. The acquisition parameters were carefully adjusted to linearly display the fluorescence signals and ensure that they fell in the maximum dynamic range of the detectors. To generate Z-stacks for each marker and each cortical field, we acquired 3 images (3.5- $\mu \mathrm{m}$ intervals) at a magnification of $10 \times$ and 6 images $(1.5-\mu \mathrm{m}$ intervals $)$ at $20 \times$. Original images were processed with ImageJ (National Institutes of Health, USA) to adjust the brightness and contrast, and then exported as TIFF images. We used MatLab (2014a, Mathworks, USA) and ImageJ to calculate the total number of cells in regions of interest. To count the number of cells labeled by a particular marker, we set a threshold of fluorescence intensity and only those above the threshold were counted. In our experiments, it was clear that the labeled cells showed a much higher fluorescence intensity 
than the background. Positive cells were also determined by soma size. For instance, NeuN-labeled cells with a soma size between 5 and $35 \mu \mathrm{m}$ in diameter were counted.

We identified cortical layers using the following characteristics of different layers, assisted by a MatLab code that determined the soma size and density of NeuN-labeled cells. Positively-labeled cells in layer I were sparse. Compared with layer III, layer II had a higher cell density but the cells were smaller. Layer IV had a higher cell density than its neighboring layers (III and V). Layer V had the largest pyramidal cells. Layer VI cells were smaller than layer V cells. The border between layer VI and the white matter was determined by a sharp decrease in cell density.

\section{Results}

\section{Specificity of Antibodies}

We performed control experiments to confirm the specificity of the primary and secondary antibodies (Supplementary Table S1). We followed the protocols described in the Methods but with some changes in the procedures. To assess the specificity of the secondary antibodies, for each primary antibody (NeuN, PV, SST, CCK, NPY, and TH), we applied all three secondary antibodies. We found that only the corresponding secondary antibody showed positive signals (Fig. 1A, SST primary antibody). Next, we
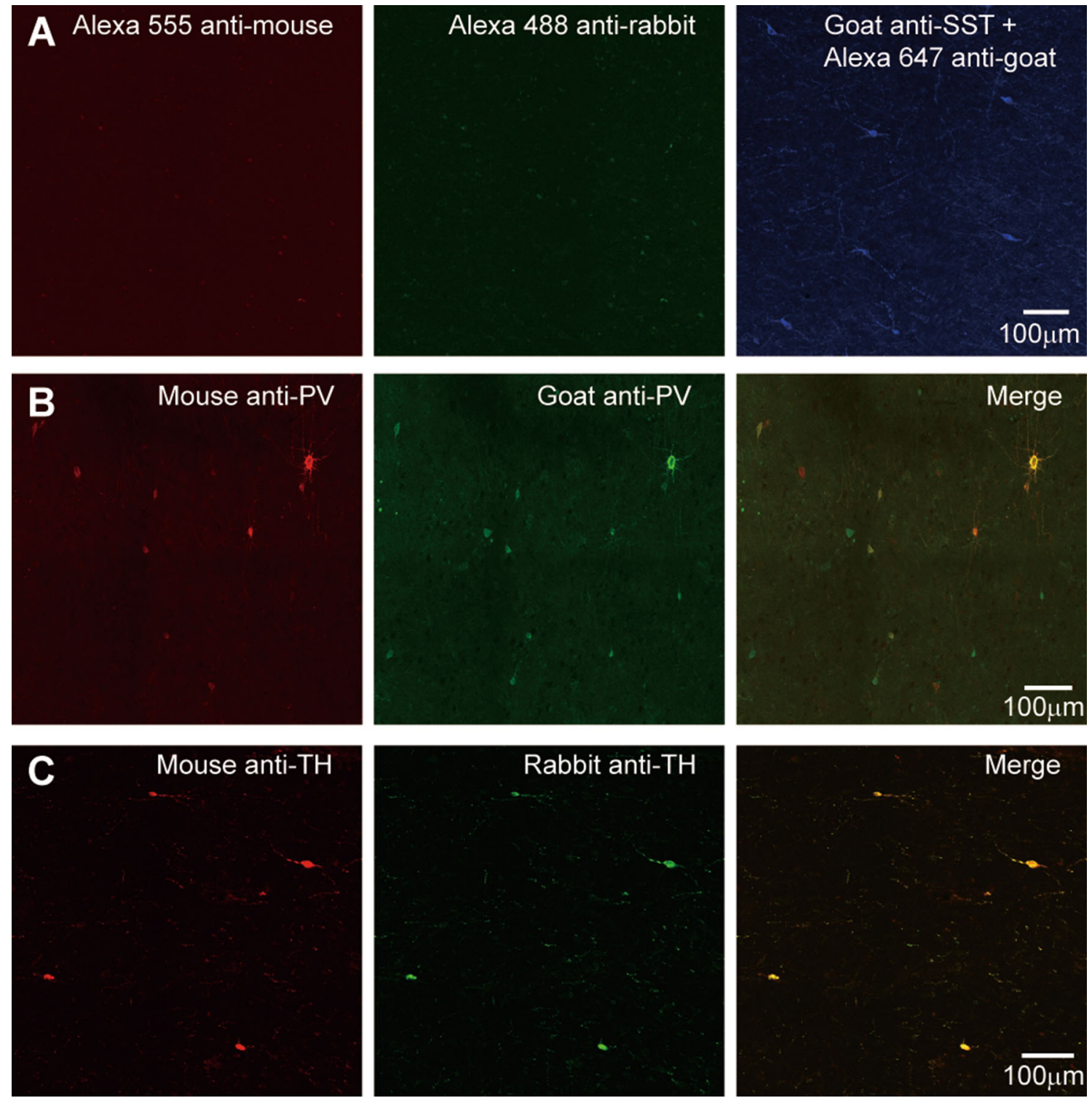

Fig. 1 Control experiments assessing antibody specificity. A Goat anti-SST was used as the only primary antibody and followed by the three secondary antibodies. Only one channel showed positive signals (Alexa 647 anti-goat). B Double-labeling of mouse and goat anti-PV.
Note that most of the labeled cells were positive for both primary antibodies. C Double-labeling of mouse and rabbit anti-TH. All labeled cells were positive for both primary antibodies. Cortical tissues were from patient \#9 (8 years old). 
replaced the primary antibody with bovine serum albumin and applied all the three secondary antibodies and observed no staining. In addition, we performed double-labeling using two distinct primary antibodies for PV (goat and mouse anti-PV) or TH (rabbit and mouse anti-TH) and assessed the overlap of labeled cells. The percentages of cells positive for both antibodies were $78 \%$ in goat and $90 \%$ in mouse anti-PV-labeled cells (Fig. 1B). For TH staining, the two primary antibodies labeled the same population of cells (completely overlapped, Fig. 1C).

\section{Laminar Distribution and Density of PV and SST Neurons}

In immunohistochemical experiments, we used NeuN as the neuronal marker since it is expressed by most neurons throughout the central nervous system and has been used as a neuronal marker in previous studies [45-47]. Based on double-staining for NeuN and different neurochemical markers, we determined the total number of neurons in the regions of interest as well as the distribution and density of interneuron subpopulations (Fig. 2A). In these experiments, we used tissues from patients \#1, 3, 4, 7, 8 and 9 (Table 1). We performed staining using antibodies to all the molecular markers in cortical sections from each patient. We also analyzed the cell density (number of cells per $\mathrm{mm}^{2}$ ) in different layers and the white matter.

Labeling with antibodies revealed the distribution patterns of neurons immunoreactive (ir) for PV or SST across cortical layers (Fig. 2 and Tables 2, 3, 4 and 5). We found that PV-ir neurons comprised $7.16 \% \pm 0.54 \%$ (mean \pm SEM) of NeuN-labeled gray-matter neurons ( $n=26,759$ cells from 6 patients) and located in all cortical layers except layer I, with layer IV displaying the highest density (Fig. 2A-D and Tables 2, 3). And the density of PV-ir neurons in gray matter was $34 \pm 7$ per $\mathrm{mm}^{2}$ ( $n=1632 \mathrm{PV}$ cells). Moreover, PV-ir neurons were rarely found in the white matter. The PV-ir neurons were most likely basket cells or chandelier cells, as suggested in previous studies by their somatic morphology and axonal arborization [48]. PV-ir fibers were densely distributed across all cortical layers including layer I. We also performed similar labeling in non-epileptic tissues (from patients \#10-12) and found the proportion of PV-ir cells among all cortical neurons $(6.99 \% \pm 0.25 \%, n=10,258)$ and their density in gray matter $\left(34 \pm 5\right.$ per $\left.\mathrm{mm}^{2}, n=766\right)$ were similar to the values obtained from epileptic tissues, indicating no substantial change of PV-ir cells under epileptic conditions.

SST-ir neurons constituted $2.60 \% \pm 0.31 \%$ of NeuNlabeled gray-matter neurons $(n=35,761)$ and were distributed mainly in layers IV, V, VI and the border between gray and white matter (Fig. 2E-G and Tables 2, 3). The density of SST-ir neurons in gray matter was $16 \pm 5$ per $\mathrm{mm}^{2}(n=793)$. SST-ir neurites were mainly located in deep layers; straight and long fibers crossing layers and perpendicular to the white matter were often observed (Fig. 2E and F).
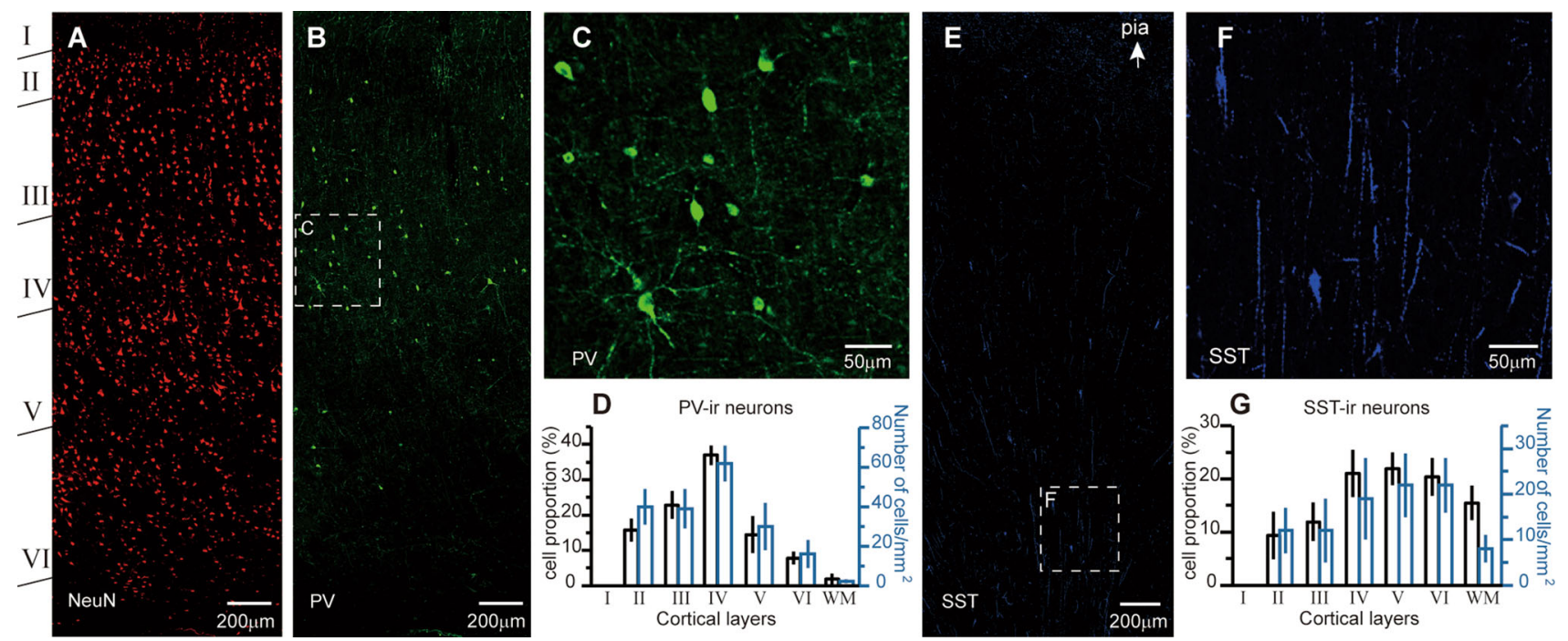

Fig. 2 Laminar distribution of PV-ir and SST-ir neurons. A NeuN immunostaining showing the identification of cortical layers I to VI and the white matter. Tissue was from the left frontal lobe of patient \#3 (14 years old). B PV labeling in the same section as in A. C Higher magnification of the boxed area in B. D Group data showing the percentage of PV-ir cells among the total PV-positive population (black, patients 1, 3, 4, 7, 8, and 9) and their density in each layer (blue, patients 7-9). E Distribution of SST-ir neurons in the right temporal lobe of patient \#1 (1.3 years old). F Higher magnification of the boxed area in E. G As in D, but for SST-ir cells. Error bars denote SEM. 
Table 2 Percentages of positive cells in each layer

\begin{tabular}{|c|c|c|c|c|c|c|c|}
\hline & I & II & III & IV & $\mathrm{V}$ & VI & wm \\
\hline \multicolumn{8}{|l|}{$P V e p$} \\
\hline 1 & 0 & $14.08 \%$ & $23.94 \%$ & $34.32 \%$ & $13.38 \%$ & $7.75 \%$ & $3.52 \%$ \\
\hline 3 & 0 & $11.40 \%$ & $26.47 \%$ & $34.93 \%$ & $19.49 \%$ & $7.72 \%$ & 0 \\
\hline 4 & 0 & $16.67 \%$ & $28.04 \%$ & $41.27 \%$ & $9.26 \%$ & $3.97 \%$ & $0.79 \%$ \\
\hline 7 & 0 & $20.28 \%$ & $20.56 \%$ & $39.43 \%$ & $9.86 \%$ & $9.30 \%$ & $0.56 \%$ \\
\hline 8 & 0 & $12.96 \%$ & $16.05 \%$ & $33.95 \%$ & $23.46 \%$ & $9.26 \%$ & $4.32 \%$ \\
\hline 9 & 0 & $18.80 \%$ & $22.07 \%$ & $38.15 \%$ & $11.17 \%$ & $8.45 \%$ & $1.36 \%$ \\
\hline Mean & 0 & $15.70 \%$ & $22.86 \%$ & $37.01 \%$ & $14.44 \%$ & $7.74 \%$ & $1.76 \%$ \\
\hline SEM & 0 & $3.17 \%$ & $3.93 \%$ & $2.78 \%$ & $5.27 \%$ & $1.80 \%$ & $1.60 \%$ \\
\hline \multicolumn{8}{|c|}{$P V$ non-ep } \\
\hline 10 & 0 & $15.81 \%$ & $19.76 \%$ & $36.36 \%$ & $19.37 \%$ & $7.11 \%$ & $1.58 \%$ \\
\hline 11 & 0 & $14.05 \%$ & $27.57 \%$ & $43.24 \%$ & $9.73 \%$ & $4.86 \%$ & $0.54 \%$ \\
\hline 12 & 0 & $16.00 \%$ & $23.00 \%$ & $39.00 \%$ & $12.00 \%$ & $7.00 \%$ & $3.00 \%$ \\
\hline Mean & 0 & $15.29 \%$ & $23.44 \%$ & $39.53 \%$ & $13.70 \%$ & $6.32 \%$ & $1.71 \%$ \\
\hline SEM & 0 & $0.88 \%$ & $3.20 \%$ & $2.83 \%$ & $4.12 \%$ & $1.04 \%$ & $1.01 \%$ \\
\hline \multicolumn{8}{|l|}{ SST ep } \\
\hline 1 & 0 & $6.82 \%$ & $12.50 \%$ & $11.36 \%$ & $26.17 \%$ & $26.14 \%$ & $17.05 \%$ \\
\hline 3 & 0 & $7.53 \%$ & $9.68 \%$ & $23.30 \%$ & $21.15 \%$ & $22.22 \%$ & $16.13 \%$ \\
\hline 4 & 0 & $19.21 \%$ & $19.49 \%$ & $20.90 \%$ & $16.10 \%$ & $14.41 \%$ & $9.89 \%$ \\
\hline 7 & 0 & $8.28 \%$ & $10.19 \%$ & $22.29 \%$ & $22.93 \%$ & $20.38 \%$ & $15.92 \%$ \\
\hline 8 & 0 & $6.45 \%$ & $8.60 \%$ & $24.73 \%$ & $21.51 \%$ & $18.28 \%$ & $20.43 \%$ \\
\hline 9 & 0 & $7.81 \%$ & $10.94 \%$ & $23.44 \%$ & $23.44 \%$ & $20.83 \%$ & $13.54 \%$ \\
\hline Mean & 0 & $9.35 \%$ & $11.90 \%$ & $21.00 \%$ & $21.88 \%$ & $20.38 \%$ & $15.49 \%$ \\
\hline SEM & 0 & $4.45 \%$ & $3.60 \%$ & $4.47 \%$ & $3.06 \%$ & $3.59 \%$ & $3.23 \%$ \\
\hline \multicolumn{8}{|l|}{ TH ep } \\
\hline 1 & 0 & $3.70 \%$ & $7.41 \%$ & $14.81 \%$ & $25.93 \%$ & $29.63 \%$ & $18.52 \%$ \\
\hline 3 & 0 & 0 & $7.14 \%$ & $7.21 \%$ & $35.66 \%$ & $35.71 \%$ & $14.29 \%$ \\
\hline 4 & 0 & 0 & $5.26 \%$ & $15.79 \%$ & $21.05 \%$ & $31.58 \%$ & $26.32 \%$ \\
\hline 7 & 0 & 0 & $5.26 \%$ & $15.79 \%$ & $31.58 \%$ & $26.32 \%$ & $18.42 \%$ \\
\hline 8 & 0 & 0 & $8.33 \%$ & $8.33 \%$ & $33.33 \%$ & $33.33 \%$ & $16.67 \%$ \\
\hline 9 & 0 & 0 & $10.42 \%$ & $22.92 \%$ & $35.42 \%$ & $20.83 \%$ & $10.42 \%$ \\
\hline Mean & 0 & $0.62 \%$ & $7.30 \%$ & $14.14 \%$ & $30.50 \%$ & $29.57 \%$ & $17.44 \%$ \\
\hline SEM & 0 & $1.39 \%$ & $1.79 \%$ & $5.24 \%$ & $5.32 \%$ & $4.88 \%$ & $4.84 \%$ \\
\hline \multicolumn{8}{|c|}{$N P Y$ ep } \\
\hline 1 & 0 & 0 & 0 & $12.33 \%$ & $14.33 \%$ & $20.00 \%$ & $53.33 \%$ \\
\hline 3 & 0 & 0 & 0 & $15.79 \%$ & $21.05 \%$ & $21.05 \%$ & $42.11 \%$ \\
\hline 4 & 0 & 0 & 0 & $15.38 \%$ & $7.69 \%$ & $19.23 \%$ & $57.69 \%$ \\
\hline 7 & 0 & 0 & 0 & $16.00 \%$ & $16.00 \%$ & $20.00 \%$ & $48.00 \%$ \\
\hline 8 & 0 & 0 & 0 & $7.15 \%$ & $14.28 \%$ & $35.71 \%$ & $42.86 \%$ \\
\hline 9 & 0 & 0 & 0 & $12.50 \%$ & $16.67 \%$ & $33.33 \%$ & $45.83 \%$ \\
\hline Mean & 0 & 0 & 0 & $13.19 \%$ & $15.00 \%$ & $24.89 \%$ & $48.30 \%$ \\
\hline SEM & 0 & 0 & 0 & $3.09 \%$ & $3.97 \%$ & $6.87 \%$ & $5.59 \%$ \\
\hline \multicolumn{8}{|c|}{ CCK ep } \\
\hline 1 & 0 & $15.07 \%$ & $13.70 \%$ & $34.25 \%$ & $8.22 \%$ & $24.66 \%$ & $4.11 \%$ \\
\hline 3 & 0 & $6.45 \%$ & $13.98 \%$ & $32.26 \%$ & $16.13 \%$ & $27.96 \%$ & $3.23 \%$ \\
\hline 4 & 0 & $21.43 \%$ & $24.29 \%$ & $30.00 \%$ & $7.14 \%$ & $15.71 \%$ & $1.43 \%$ \\
\hline 7 & 0 & $11.49 \%$ & $12.16 \%$ & $32.43 \%$ & $12.16 \%$ & $30.41 \%$ & $1.35 \%$ \\
\hline 8 & 0 & $11.35 \%$ & $20.87 \%$ & $30.81 \%$ & $14.05 \%$ & $28.65 \%$ & 0 \\
\hline 9 & 0 & $9.87 \%$ & $11.16 \%$ & $32.62 \%$ & $12.02 \%$ & $32.19 \%$ & $2.15 \%$ \\
\hline Mean & 0 & $12.61 \%$ & $16.03 \%$ & $32.06 \%$ & $11.62 \%$ & $26.60 \%$ & $2.05 \%$ \\
\hline SEM & 0 & $4.69 \%$ & $4.83 \%$ & $1.36 \%$ & $3.12 \%$ & $5.39 \%$ & $1.34 \%$ \\
\hline
\end{tabular}

ep: epileptic; non-ep: non-epileptic; wm: white matter. 
Table 3 Cell density in NeuN-labeled cells (counts per $\mathrm{mm}^{2}$ )

\begin{tabular}{|c|c|c|c|c|c|c|c|c|}
\hline & I & II & III & IV & $\mathrm{V}$ & VI & wm & $\mathrm{gm}$ \\
\hline \multicolumn{9}{|l|}{$P V-e p$} \\
\hline 1 & 0 & 33 & 25 & 47 & 19 & 10 & 2 & 23 \\
\hline 3 & 0 & 31 & 52 & 66 & 39 & 15 & 0 & 34 \\
\hline 4 & 0 & 32 & 30 & 63 & 20 & 6 & 1 & 29 \\
\hline 7 & 0 & 50 & 51 & 70 & 28 & 25 & 1 & 44 \\
\hline 8 & 0 & 52 & 40 & 74 & 51 & 18 & 4 & 43 \\
\hline 9 & 0 & 39 & 36 & 54 & 23 & 22 & 3 & 33 \\
\hline Mean & 0 & 40 & 39 & 62 & 30 & 16 & 2 & 34 \\
\hline SEM & 0 & 9 & 10 & 9 & 12 & 7 & 1 & 7 \\
\hline \multicolumn{9}{|c|}{$P V$ non-ep } \\
\hline 10 & 0 & 33 & 37 & 88 & 49 & 32 & 2 & 37 \\
\hline 11 & 0 & 49 & 45 & 76 & 20 & 13 & 1 & 39 \\
\hline 12 & 0 & 33 & 41 & 66 & 16 & 9 & 1 & 27 \\
\hline Mean & 0 & 38 & 41 & 77 & 28 & 18 & 1 & 34 \\
\hline SEM & 0 & 8 & 3 & 9 & 15 & 10 & 1 & 5 \\
\hline \multicolumn{9}{|c|}{ SST ep } \\
\hline 1 & 0 & 5 & 5 & 6 & 13 & 13 & 4 & 8 \\
\hline 3 & 0 & 7 & 6 & 14 & 15 & 21 & 6 & 13 \\
\hline 4 & 0 & 20 & 26 & 34 & 25 & 25 & 9 & 23 \\
\hline 7 & 0 & 14 & 15 & 24 & 24 & 25 & 15 & 19 \\
\hline 8 & 0 & 13 & 7 & 14 & 18 & 16 & 7 & 13 \\
\hline 9 & 0 & 10 & 15 & 23 & 34 & 29 & 9 & 18 \\
\hline Mean & 0 & 12 & 12 & 19 & 22 & 22 & 8 & 16 \\
\hline SEM & 0 & 5 & 7 & 9 & 7 & 6 & 3 & 5 \\
\hline \multicolumn{9}{|c|}{ TH ep } \\
\hline 1 & 0 & 1 & 1 & 3 & 6 & 9 & 3 & 4 \\
\hline 3 & 0 & 0 & 2 & 2 & 5 & 8 & 2 & 3 \\
\hline 4 & 0 & 0 & 1 & 2 & 5 & 6 & 2 & 3 \\
\hline 7 & 0 & 0 & 2 & 4 & 8 & 8 & 4 & 4 \\
\hline 8 & 0 & 0 & 1 & 1 & 3 & 3 & 1 & 1 \\
\hline 9 & 0 & 0 & 2 & 3 & 8 & 7 & 5 & 3 \\
\hline Mean & 0 & 1 & 2 & 3 & 6 & 7 & 3 & 3 \\
\hline SEM & 0 & 1 & 1 & 1 & 2 & 2 & 1 & 1 \\
\hline \multicolumn{9}{|c|}{ NPY ep } \\
\hline 1 & 0 & 0 & 0 & 2 & 2 & 4 & 7 & 1 \\
\hline 3 & 0 & 0 & 0 & 1 & 4 & 6 & 4 & 2 \\
\hline 4 & 0 & 0 & 0 & 3 & 3 & 7 & 5 & 2 \\
\hline 7 & 0 & 0 & 0 & 6 & 6 & 9 & 13 & 2 \\
\hline 8 & 0 & 0 & 0 & 2 & 5 & 14 & 7 & 4 \\
\hline 9 & 0 & 0 & 0 & 2 & 4 & 2 & 8 & 2 \\
\hline Mean & 0 & 0 & 0 & 3 & 4 & 7 & 7 & 2 \\
\hline SEM & 0 & 0 & 0 & 2 & 1 & 4 & 3 & 1 \\
\hline \multicolumn{9}{|c|}{$C C K e p$} \\
\hline 1 & 0 & 15 & 11 & 33 & 7 & 23 & 1 & 16 \\
\hline 3 & 0 & 8 & 14 & 33 & 14 & 28 & 2 & 21 \\
\hline 4 & 0 & 18 & 11 & 36 & 26 & 26 & 1 & 14 \\
\hline 7 & 0 & 19 & 16 & 33 & 21 & 58 & 1 & 24 \\
\hline 8 & 0 & 36 & 41 & 52 & 28 & 57 & 0 & 34 \\
\hline
\end{tabular}

Table 3 continued

\begin{tabular}{lrrrrrrrr}
\hline & I & II & III & IV & V & VI & wm & gm \\
\hline 9 & 0 & 19 & 19 & 38 & 18 & 54 & 2 & 29 \\
Mean & 0 & 19 & 19 & 38 & 19 & 41 & 1 & 23 \\
SEM & 0 & 8 & 10 & 7 & 7 & 15 & 1 & 7 \\
\hline
\end{tabular}

ep: epileptic; non-ep: non-epileptic; gm: gray matter; wm: white matter.

Laminar Distribution and Density of NPY, TH, and CCK Neurons

Next, we investigated the distribution patterns of TH-ir, NPY-ir, and CCK-ir neurons (Fig. 3 and Tables 2, 3). TH-ir (Fig. 3A, B, C, F) and NPY-ir (Fig. 3D, G) neurons were distributed mainly in layers $\mathrm{V}$ and $\mathrm{VI}$ and the white matter, taking up $0.53 \% \pm 0.14 \%(\mathrm{~V}$ and VI; $n=35,448)$ and $0.51 \% \pm 0.06 \%$ (white matter; $n=26,859$ ) of the total cortical neurons. The density of TH-ir and NPY-ir neurons in the gray matter were $3 \pm 1(n=144)$ and $2 \pm 1$ per $\mathrm{mm}^{2}$ $(n=132)$, respectively. Most of the TH-ir neurons were bipolar or bitufted cells (Fig. 3A, C), and many NPY-ir neurons emitted two main dendrites in different directions (Fig. 3D). The TH and NPY antibodies also labeled a mass of long fibers in layer I and the white matter. In layer I, these fibers were horizontal and parallel to the pia. TH-ir fibers were present in the superficial layers (Fig. 2B). It should be noted that most of these $\mathrm{TH}$ fibers may come from subcortical dopaminergic or noradrenergic neurons [39].

CCK-ir neurons were concentrated in layers IV and VI, and a much lower density was observed in other layers. They constituted $4.38 \% \pm 0.47 \%$ of all cortical neurons $(n=28,563)$, and their density in the gray matter was $23 \pm 7$ per $\mathrm{mm}^{2}(n=1434)$. Because the neurites of CCKir neurons were only weakly labeled, their distribution pattern was unclear. The majority of CCK-ir neurons possessed a round or oval soma (Fig. 3E). Previous experiments have revealed that a subpopulation of pyramidal cells express CCK [7]. We also found a similar pattern (except for samples from the infant patient \#1); however, the fluorescence immunosignals were relatively weaker than in non-pyramidal cells. Since we focused on cortical interneurons, we only included the strongly-labeled non-pyramidal neurons for data analysis.

\section{Co-localization of NPY, CCK, and TH with PV and SST}

Although many molecular markers have been used to identity different interneuron types, none can actually define a cell type. Given that two or more molecular markers can be expressed in a single cell type, we next 
Table 4 Percentage of positive cells among NeuN-labeled cells in gray matter of epileptic tissue

\begin{tabular}{lllllllll}
\hline & $1(\%)$ & $3(\%)$ & $4(\%)$ & $7(\%)$ & $8(\%)$ & $9(\%)$ & Mean $(\%)$ & SEM $(\%)$ \\
\hline PV & 6.55 & 7.84 & 6.99 & 7.94 & 6.71 & 6.92 & 7.16 & 0.54 \\
SST & 2.16 & 2.65 & 3.12 & 2.44 & 2.43 & 2.81 & 2.60 & 0.31 \\
TH & 0.23 & 0.58 & 0.53 & 0.65 & 0.54 & 0.67 & 0.53 & 0.15 \\
NPY & 0.40 & 0.59 & 0.53 & 0.49 & 0.56 & 0.51 & 0.51 & 0.06 \\
CCK & 4.48 & 5.26 & 3.76 & 4.37 & 4.42 & 4.01 & 4.38 & 0.47 \\
\hline
\end{tabular}

Table 5 Percentages of cells co-expressing PV or SST among the total TH-positive cell population in different patients

\begin{tabular}{lll}
\hline Patient number & $\mathrm{PV}^{+} \mathrm{TH}^{+} / \mathrm{TH}^{+}$ & $\mathrm{SST}^{+} \mathrm{TH}^{+} / \mathrm{TH}^{+}$ \\
\hline 1 & $26.1 \%(6 / 23)$ & $13.0 \%(3 / 23)$ \\
3 & $9.67 \%(3 / 31)$ & $38.7 \%(12 / 31)$ \\
4 & $12.5 \%(2 / 16)$ & $43.8 \%(7 / 16)$ \\
5 & $8.33 \%(1 / 12)$ & $40.0 \%(14 / 35)$ \\
\hline
\end{tabular}

sought to clarify the overlap between PV-ir and SST-ir cells and those containing NPY-ir, CCK-ir, or TH-ir.

Several distinct subpopulations of NPY-containing neurons have been reported in rat and monkey cortex, one of which co-expresses SST [49-51]. Consistent with these reports, our results revealed that $97.7 \% \pm 1.5 \%$ of NPY-ir interneurons $(n=43)$ in epileptic human cortex also expressed SST, and these co-expressing neurons were $38.2 \% \pm 3.1 \%$ of all SST-ir neurons $(n=110)$. Since NPY neurons were only present in layers IV, V, VI, and the white matter, the co-expressing neurons were mainly located in the deep layers and absent from the superficial layers (Fig. 4A-C). In sharp contrast, we found no colocalization between PV-ir and NPY-ir (Fig. 4D). In this particular experiment, we examined the co-expression in tissues from patients \#1-6.

Our experiments showed that $34.2 \% \pm 7.3 \%$ of TH-ir neurons $(n=105)$ were SST- positive and $14.6 \% \pm 5.6 \%$ TH-ir neurons $(n=82)$ were PV-positive (Table 6$)$. In this part of work, we used the tissues from patients \#1, 3, 4, and 5 ( 1,3 , and 4 for triple-staining, and 5 for double-staining). As shown in Table 5, the percentages of TH-positive cells co-expressing PV or SST varied between patients, possibly resulting from age differences. The staining shown in Fig. 4 was performed in tissues from patients \#3 (Fig. 5A) and \#1 (Fig. 5B).

We found that $28.0 \% \pm 5.4 \%$ of CCK-ir neurons $(n=321)$ co-expressed PV in double-staining experiments (Fig. 6A). Interestingly, although CCK-positive cells were distributed from layer II to the white matter, the CCK-PVco-expressing cells were only found in layer IV. In addition, CCK-ir neurons were not labeled by the antibody to SST (Fig. 6B). We performed this double-staining in tissues from patients \#2-4.
We also examined the co-expression among NPY, TH, and CCK (Fig. 7) in double-labeling experiments. Although both TH-ir and NPY-ir neurons were located in deep layers and the white matter, we found no overlap between these cells (Fig. 7A). No co-localization between NPY and CCK (Fig. 7B) or TH and CCK (Fig. 7C) was found. These results suggest that these chemical markers identify distinct non-overlapping cell types in the neocortex. Tissues from patients \#2, 4, and 6 were used in these experiments.

\section{Discussion}

Although it is very important to understand the neural substrates of human cognitive functions, few studies have examined the cell types and their distribution in cortical circuits. Previous work in adult human cortical tissues have revealed the density and distribution patterns of certain types of neurons $[25,39,52]$. In this study, we investigated the cell density and laminar distribution of neurons expressing PV, SST, CCK, NPY, and TH in epileptic human cortex. Our results indicated that PV, SST, and CCK cells were located in cortical layers II to VI, while TH-ir and NPY-ir cells were preferentially located in deep layers from IV to the white matter. In addition, we found subpopulations of neurons labeled by two markers: $\mathrm{PV}+\mathrm{TH}, \mathrm{PV}+\mathrm{CCK}, \mathrm{SST}+\mathrm{NPY}$, and SST+TH. In contrast, we found no overlap between PV and NPY, SST and CCK, NPY and TH, NPY and CCK, and TH and CCK (Tables 5 and 6).

We used epileptic tissue to investigate the cell density and distribution of interneurons types. It remains to be further determined whether specific cell types are vulnerable to epileptic conditions. Early examination has revealed a loss of PV-positive cells in human cortical tissue [22] and the hippocampal CA1 region with temporallobe epilepsy [53]. However, it has also been reported that the percentage of PV-ir cells among all cortical neurons is relatively high $(\sim 14 \%)$, only slightly less than that of GABAergic neurons $(\sim 17 \%)$ in human epileptic cortex [54]. In non-epileptic human prefrontal cortex, PV-ir cells constitute $\sim 20 \%$ of all GABAergic neurons [26]. If GABAergic neurons comprise $20 \%-30 \%$ of the total 

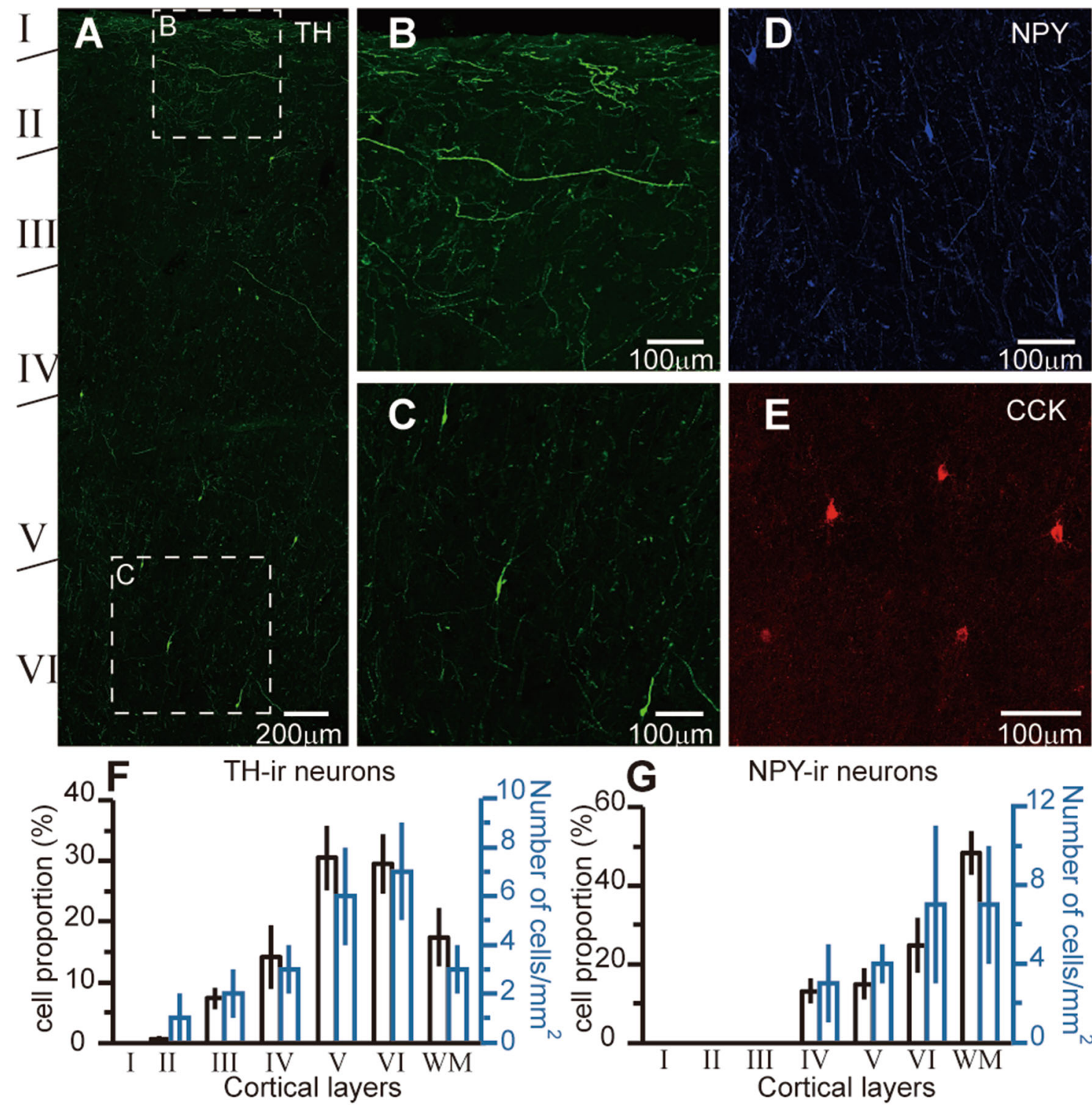

G

NPY-ir neurons
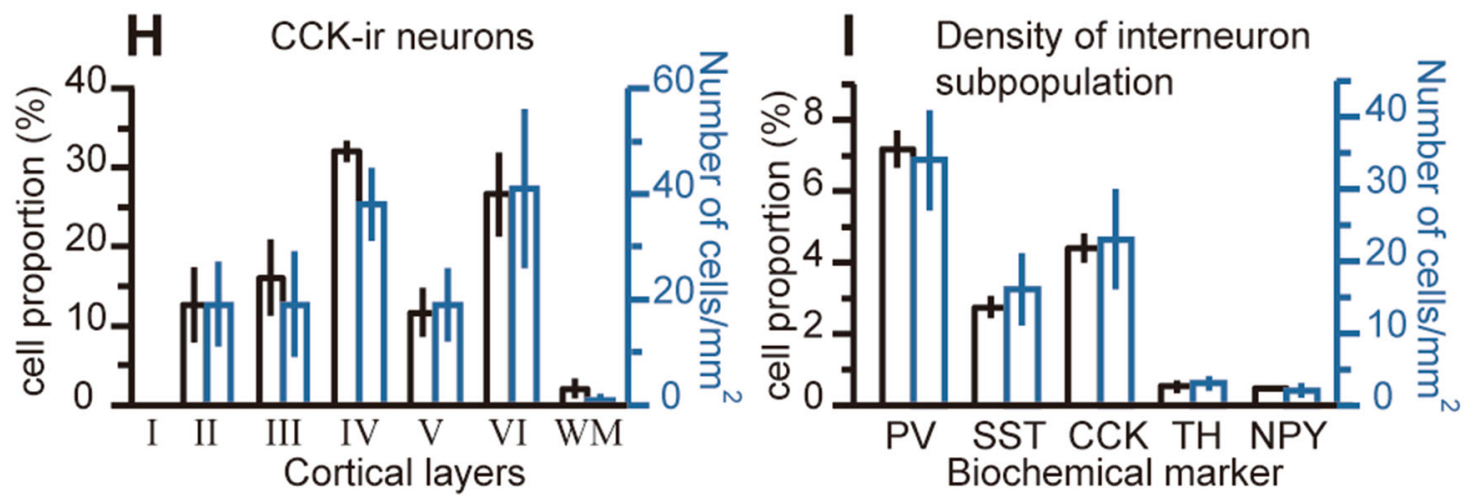

Fig. 3 Laminar distribution of TH-ir, NPY-ir, and CCK-ir neurons. A Laminar distribution of TH-ir neuron across cortical layers in the left frontal lobe of patient \#3 (14 years old). Note that TH-ir neurons were located in the deep layers. B Higher magnification of the boxed area in A. Note the dense distribution of TH-ir fibers in layers I and II. C Higher magnification of the boxed area in A. D Example of staining of NPY-ir neurons (patient \#3). E Example of staining of CCK-ir neurons in the left anterior temporal cortex of patient \#4 (16 years old). F-H Group data showing the laminar distribution of TH-ir, NPY-ir, and CCK-ir neurons (black) and their density in each layer (blue). I Percentage of cells labeled by different markers in the total cortical neuron population (black, patients \#1, 3, 4, 7, 8, and 9) and their density in gray matter (blue, patients \#7-9). Error bars denote SEM. 

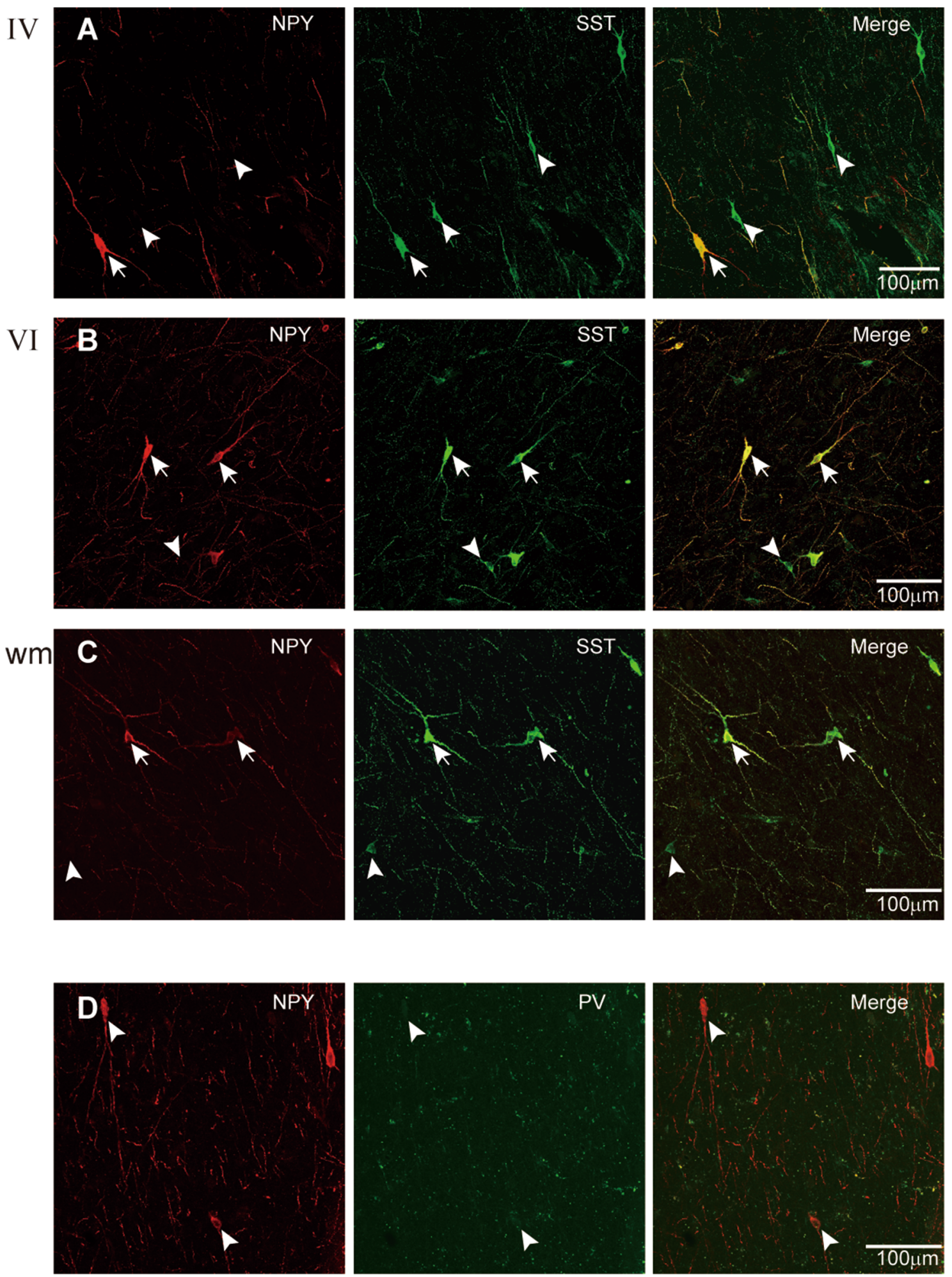

Fig. 4 Co-expression of NPY with SST or PV. A-C Double-labeling for SST and NPY in layers IV (A), VI (B), and the white matter (C). Arrows indicate cells co-expressing NPY and SST; arrowheads indicate cells without co-expression. Note that NPY and SST were highly co-localized in layer VI and white matter cells. D Doublestaining for NPY and PV showing that all the three NPY cells were PV-negative. Images were from tissues of patient \#1 (1.3 years old). 
Table 6 Percentages (mean \pm SEM) of cells showing co-expression in the total population of PV, SST, TH, NPY, or CCK-positive cells

\begin{tabular}{|c|c|c|c|c|c|}
\hline \multirow[t]{2}{*}{ Neurons containing } & \multicolumn{5}{|c|}{ Percentage showing co-localization } \\
\hline & PV & SST & $\mathrm{TH}$ & NPY & $\mathrm{CCK}$ \\
\hline PV & - & - & $1.11 \% \pm 0.33 \%$ & 0 & $15.6 \% \pm 3.1 \%$ \\
\hline SST & - & - & $9.30 \% \pm 1.18 \%$ & $38.2 \% \pm 3.1 \%$ & 0 \\
\hline TH & $14.6 \% \pm 5.6 \%$ & $34.2 \% \pm 7.3 \%$ & - & 0 & $1.79 \% \pm 0.67 \%$ \\
\hline NPY & 0 & $97.7 \% \pm 1.5 \%$ & 0 & - & 0 \\
\hline CCK & $28.0 \% \pm 5.4 \%$ & 0 & $0.25 \% \pm 0.09 \%$ & 0 & - \\
\hline
\end{tabular}
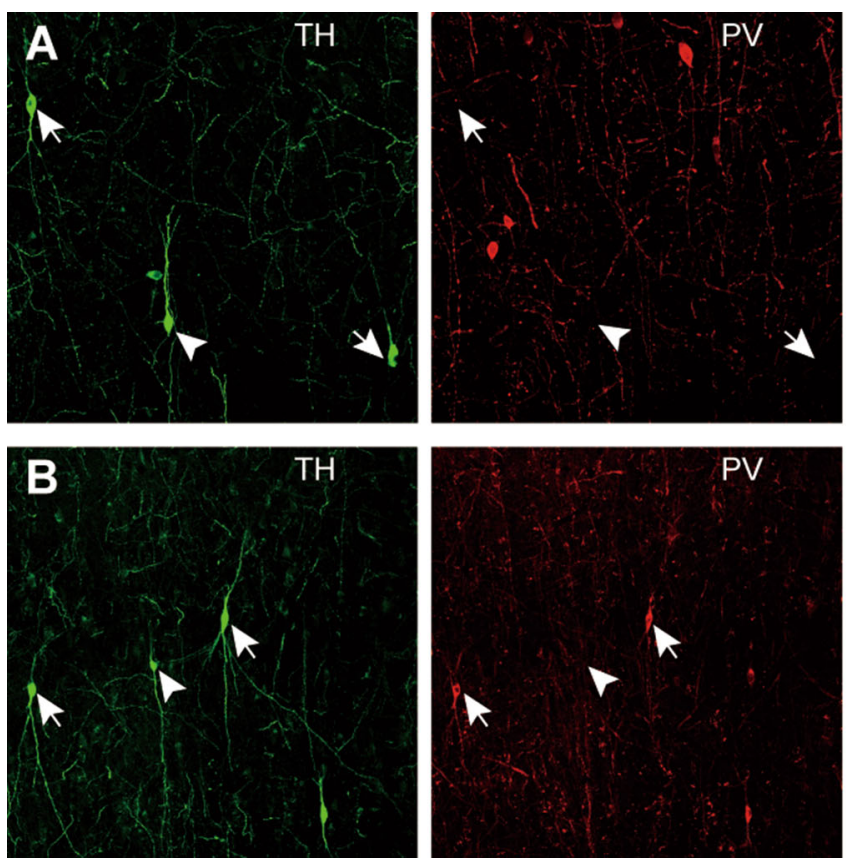

Fig. 5 Co-expression of TH with PV and SST. A Triple-labeling for $\mathrm{TH}, \mathrm{PV}$, and SST in tissues from the left frontal lobe (patient \#3, 14 years old). TH-positive cells were more likely to co-express SST. Arrows indicate cells with TH and SST co-expression; arrowheads point to a TH cell without SST or PV expression. B Labeling as in

cortical neuron population $[2,3,55,56]$, the estimated percentage of PV-ir cells in the cortex would be 4\%-6\%. In agreement with this estimate, our results from non-epileptic human tissue revealed that $\sim 7 \%$ of all cortical neurons showed PV-ir (data not shown), similar to that observed in epileptic tissue (7\%, Fig. 2 and Table 4). In addition, the laminar distribution pattern of PV-ir neurons in epileptic tissue (Fig. 2 and Tables 2,3) was also similar to that in non-epileptic tissue [26]. Since we chose to use tissue sections showing clear stratification (from layer I to the white matter) without any structural abnormality, they represented relatively normal tissue surrounding the epileptogenic zone. Indeed, the PV-ir cell density $(\sim 34$ per $\mathrm{mm}^{2}$, Table 3 ) was comparable to that in non-epileptic
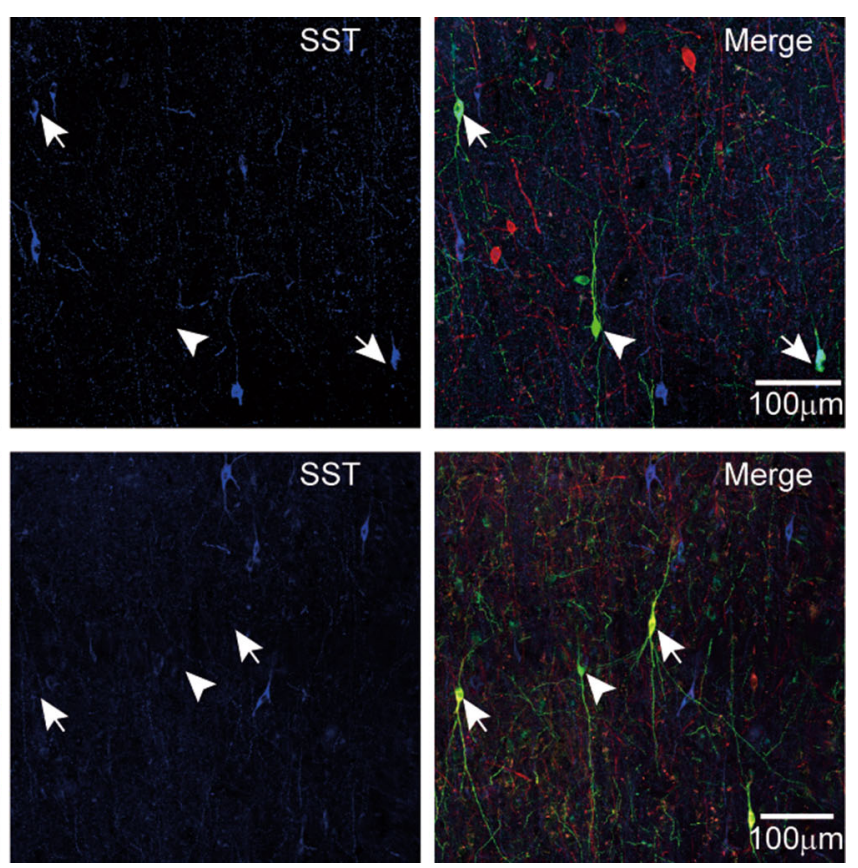

A but from patient \#1 (right temporal lobe, 1.3 years old). TH-positive cells were more likely to co-express PV. Arrows point to a TH-ir neuron co-expressing PV, while arrowheads indicate a TH-ir neuron with no PV labeling.

peri-tumor tissue in our experiments, and similar to the PV density in cortical tissue without abnormal spiking (35 per $\left.\mathrm{mm}^{2}\right)$ [25] and cryptogenic tissue $\left(\sim 42\right.$ per $\left.\mathrm{mm}^{2}\right)$ [57]. However, the density was higher than that in the epileptogenic zone of epilepsy patients $\left(\sim 20\right.$ per $\left.\mathrm{mm}^{2}\right)$ [57], suggesting that only PV neurons in the epileptogenic zone are vulnerable to epileptic conditions.

Distinct from PV-ir cells, however, other cell types might be vulnerable to epileptic conditions. The cell densities of SST-ir and NPY-ir neurons in relatively normal tissue have been reported as $\sim 40$ and 17 per $\mathrm{mm}^{2}$, respectively [25], much higher than in our experiments (16 and 2 per $\mathrm{mm}^{2}$, Table 3 ), suggesting a substantial reduction of SST-ir and NPY-ir cells in epileptic conditions. Previous 

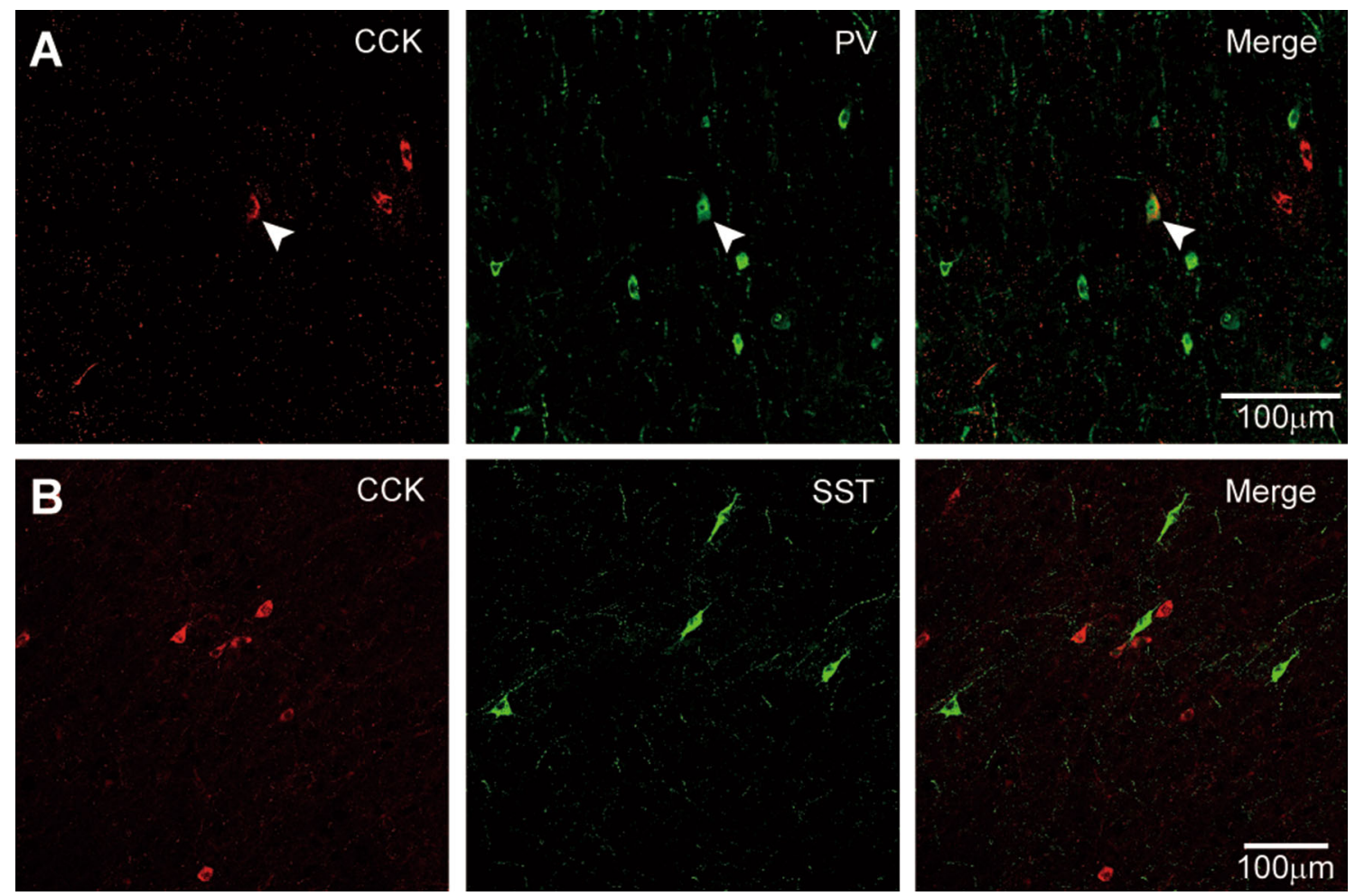

Fig. 6 Co-expression of CCK with PV or SST. A Double-labeling for CCK and PV in the left anterior temporal cortex of patient \#4 (16 years old). Arrowheads indicate a cell positive for both CCK and PV. Note the absence of PV-ir in the other two CCK-positive cells.

studies have shown that NPY neurons are widely distributed throughout the cortex but more frequently in layers II, III, and IV [51, 58, 59]. However, our results revealed that NPY neurons were mainly present in deep layers (IV, $\mathrm{V}$, and VI) and the white matter. A similar deep-layer distribution pattern of $\mathrm{TH}$-ir cells was observed in our immunostaining experiments, consistent with previous findings in human tissue [37, 39, 60]. CCK-ir cells may also be subject to alterations in epileptic conditions. The CCK mRNA expression level in the rodent cortex increases after multiple consecutive kindled seizures [61]. In our experiments, we used tissues from infant, teenage, and adult patients (\#1, 3, 4, 7, 8, and 9; Table 1) and found, in general, no clear difference in cell proportions and laminar distribution patterns for most of the markers, suggesting that cell distribution does not change during early development. The proportion of TH-positive cells in the whole population of cortical neurons in the infant patient was relatively lower, possibly due to the high neuronal density in early developmental stages. Moreover, we found that the percentages of positive cells in all cortical neurons showed little difference between patients with different durations of epilepsy (Table 1).

In the co-expression experiments, we found that NPY-ir cells did not express PV, TH, or CCK, and CCK cells did
B Double-labeling for SST and CCK in the left anterior temporal cortex of patient \#2 (1.6 years old). Note the absence of co-expressing cells.

not express SST and TH. Previous studies in rodents have shown that only a subpopulation of NPY neurons express SST [49-51]; our results indicated, however, that most NPY cells were positive for SST but negative for PV. We also found that subpopulations of TH cells also expressed PV or SST. In these experiments, we used tissues from different brain regions including the frontal or temporal lobes. Apart from the infant patient (\#1) who showed distinct co-expression patterns between TH and PV or SST, we found no evident difference in the co-expression of different markers, indicating a similar co-expression pattern across different brain regions.

Together, our results revealed the distribution pattern and the overlap of biochemically-identified cortical GABAergic neurons. The results also suggested that the density and laminar distribution of PV-ir cells are largely preserved in epileptic tissue. However, whether other interneuron types (e.g. SST, CCK, NPY, and TH) change in response to epileptic seizures remains to be further examined. In addition to the markers used in the current study, non-pyramidal GABAergic neurons in the cortex also express other neuropeptides, calcium-binding proteins, and neurotransmitter receptor markers, such as vasoactive intestinal polypeptide, nitric oxide synthase, calretinin, calbindin, and 5-hydroxytryptamine $3 \mathrm{a}$ receptor. The 

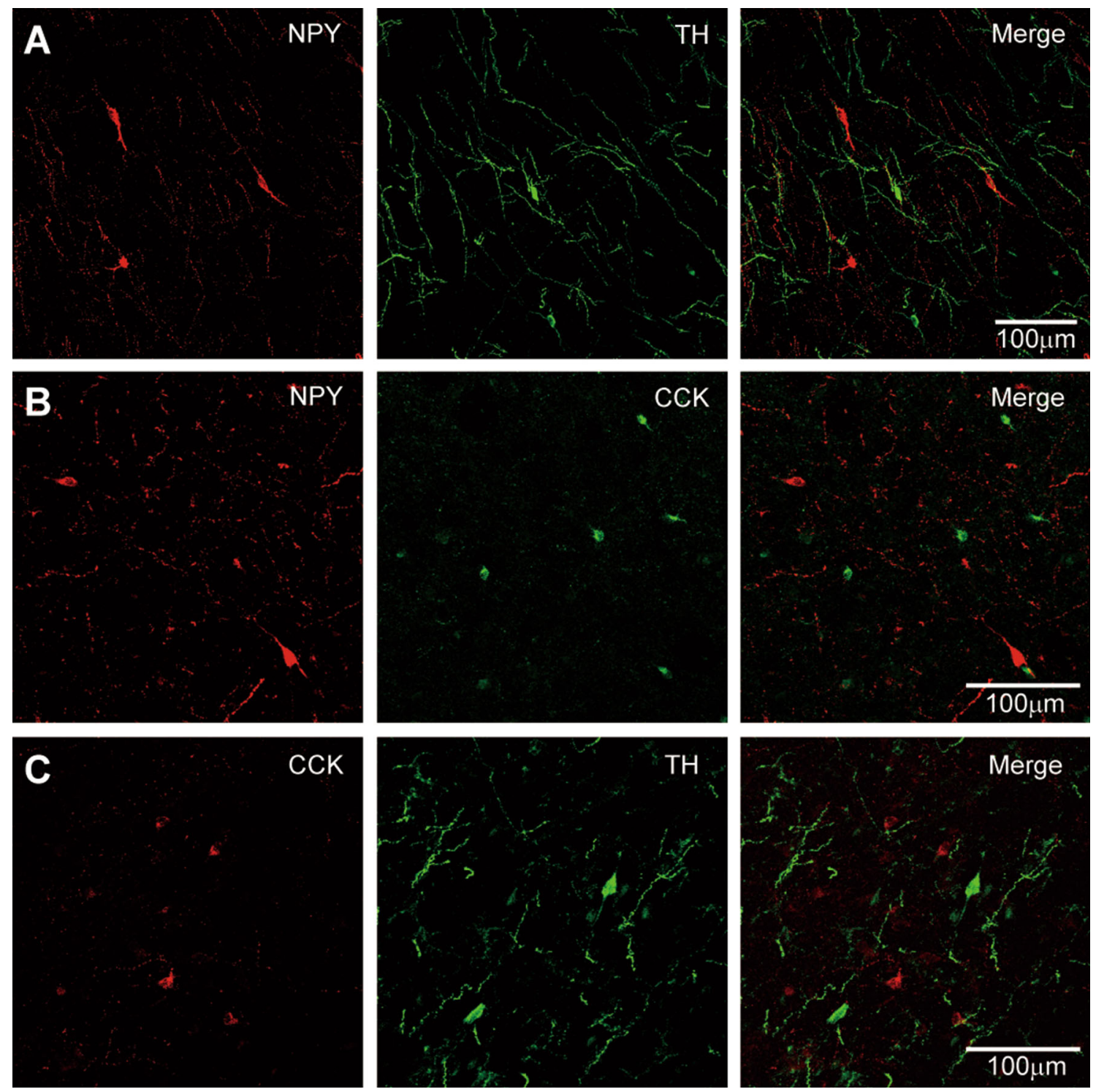

Fig. 7 No overlap of TH-, NPY-, and CCK-positive cells. A Doublelabeling for NPY and TH in the left anterior temporal lobe of patient \#2 (1.6 years old). B Double-labeling for NPY and CCK in the left

distribution patterns of these neurons in the human cortex need to be examined in future studies.

Acknowledgements This work was supported by the National Natural Science Foundation of China (31430038 and 81571275).

Open Access This article is distributed under the terms of the Creative Commons Attribution 4.0 International License (http:// creativecommons.org/licenses/by/4.0/), which permits unrestricted use, distribution, and reproduction in any medium, provided you give appropriate credit to the original author(s) and the source, provide a link to the Creative Commons license, and indicate if changes were made. anterior temporal lobe of patient \#6. $\mathbf{C}$ As in $\mathbf{B}$, but with doublestaining for TH and CCK (patient \#6, 28 years old). Note the absence of cells co-expressing any two of the three markers.

\section{References}

1. Mody I, Pearce RA. Diversity of inhibitory neurotransmission through $\operatorname{GABA}(A)$ receptors. Trends Neurosci 2004, 27: 569-575.

2. Markram H, Toledo-Rodriguez M, Wang Y, Gupta A, Silberberg $\mathrm{G}, \mathrm{Wu} \mathrm{C}$. Interneurons of the neocortical inhibitory system. Nat Rev Neurosci 2004, 5: 793-807.

3. Pfeffer CK, Xue M, He M, Huang ZJ, Scanziani M. Inhibition of inhibition in visual cortex: the logic of connections between molecularly distinct interneurons. Nat Neurosci 2013, 16: 1068-1076.

4. Gonchar Y, Burkhalter A. Three distinct families of GABAergic neurons in rat visual cortex. Cereb Cortex 1997, 7: 347-358.

5. Rudy B, Fishell G, Lee S, Hjerling-Leffler J. Three groups of interneurons account for nearly $100 \%$ of neocortical GABAergic neurons. Dev Neurobiol 2011, 71: 45-61. 
6. Wamsley B, Fishell G. Genetic and activity-dependent mechanisms underlying interneuron diversity. Nat Rev Neurosci 2017, 18: 299-309.

7. Varga C, Tamas G, Barzo P, Olah S, Somogyi P. Molecular and electrophysiological characterization of GABAergic interneurons expressing the transcription factor COUP-TFII in the adult human temporal cortex. Cereb Cortex 2015, 25: 4430-4449.

8. Kepecs A, Fishell G. Interneuron cell types are fit to function. Nature 2014, 505: 318-326.

9. Gonchar Y, Wang Q, Burkhalter A. Multiple distinct subtypes of GABAergic neurons in mouse visual cortex identified by triple immunostaining. Front Neuroanat 2007, 1: 3.

10. Silberberg G, Markram H. Disynaptic inhibition between neocortical pyramidal cells mediated by Martinotti cells. Neuron 2007, 53: 735-746.

11. Silberberg G. Polysynaptic subcircuits in the neocortex: spatial and temporal diversity. Curr Opin Neurobiol 2008, 18: 332-337.

12. Ren M, Yoshimura Y, Takada N, Horibe S, Komatsu Y. Specialized inhibitory synaptic actions between nearby neocortical pyramidal neurons. Science 2007, 316: 758-761.

13. Li T, Tian C, Scalmani P, Frassoni C, Mantegazza M, Wang Y, et al. Action potential initiation in neocortical inhibitory interneurons. PLoS Biol 2014, 12: e1001944.

14. Marin O. Interneuron dysfunction in psychiatric disorders. Nat Rev Neurosci 2012, 13: 107-120.

15. Nakazawa K, Zsiros V, Jiang Z, Nakao K, Kolata S, Zhang S, et al. GABAergic interneuron origin of schizophrenia pathophysiology. Neuropharmacology 2012, 62: 1574-1583.

16. Lewis DA. GABAergic local circuit neurons and prefrontal cortical dysfunction in schizophrenia. Brain Res Brain Res Rev 2000, 31: 270-276.

17. Rubenstein JL, Merzenich MM. Model of autism: increased ratio of excitation/inhibition in key neural systems. Genes Brain Behav 2003, 2: 255-267.

18. van Rijckevorsel K. Cognitive problems related to epilepsy syndromes, especially malignant epilepsies. Seizure 2006, 15: 227-234.

19. Alherz F, Alherz M, Almusawi H. NMDAR hypofunction and somatostatin-expressing GABAergic interneurons and receptors: A newly identified correlation and its effects in schizophrenia. Schizophr Res Cogn 2017, 8: 1-6.

20. Scharfman HE. The neurobiology of epilepsy. Curr Neurol Neurosci Rep 2007, 7: 348-354.

21. Liu YQ, Yu F, Liu WH, He XH, Peng BW. Dysfunction of hippocampal interneurons in epilepsy. Neurosci Bull 2014, 30: 985-998.

22. Marco P, Sola RG, Pulido P, Alijarde MT, Sanchez A, Ramon y Cajal S, et al. Inhibitory neurons in the human epileptogenic temporal neocortex. An immunocytochemical study. Brain 1996, 119 (Pt 4): 1327-1347.

23. Martinello K, Sciaccaluga M, Morace R, Mascia A, Arcella A, Esposito $\mathrm{V}$, et al. Loss of constitutive functional gammaaminobutyric acid type A-B receptor crosstalk in layer 5 pyramidal neurons of human epileptic temporal cortex. Epilepsia 2018, 59: 449-459.

24. Wonders CP, Anderson SA. The origin and specification of cortical interneurons. Nat Rev Neurosci 2006, 7: 687-696.

25. Gonzalez-Albo MC, Elston GN, DeFelipe J. The human temporal cortex: characterization of neurons expressing nitric oxide synthase, neuropeptides and calcium-binding proteins, and their glutamate receptor subunit profiles. Cereb Cortex 2001, 11: $1170-1181$.

26. Fish KN, Rocco BR, Lewis DA. Laminar distribution of subsets of GABAergic axon terminals in human prefrontal cortex. Front Neuroanat 2018, 12: 9.
27. Lewis DA, Campbell MJ, Morrison JH. An immunohistochemical characterization of somatostatin-28 and somatostatin-281-12 in monkey prefrontal cortex. J Comp Neurol 1986, 248: 1-18.

28. Seney ML, Tripp A, McCune S, Lewis DA, Sibille E. Laminar and cellular analyses of reduced somatostatin gene expression in the subgenual anterior cingulate cortex in major depression. Neurobiol Dis 2015, 73: 213-219.

29. Chen G, Zhang Y, Li X, Zhao X, Ye Q, Lin Y, et al. Distinct inhibitory circuits orchestrate cortical beta and gamma band oscillations. Neuron 2017, 96: 1403-1418.

30. Takada N, Pi HJ, Sousa VH, Waters J, Fishell G, Kepecs A, et al. A developmental cell-type switch in cortical interneurons leads to a selective defect in cortical oscillations. Nat Commun 2014, 5: 5333.

31. Bartos M, Vida I, Jonas P. Synaptic mechanisms of synchronized gamma oscillations in inhibitory interneuron networks. Nat Rev Neurosci 2007, 8: 45-56.

32. Yekhlef L, Breschi GL, Lagostena L, Russo G, Taverna S. Selective activation of parvalbumin- or somatostatin-expressing interneurons triggers epileptic seizurelike activity in mouse medial entorhinal cortex. J Neurophysiol 2015, 113: 1616-1630.

33. Cheung A, Newland PL, Zaben M, Attard GS, Gray WP. Intracellular nitric oxide mediates neuroproliferative effect of neuropeptide y on postnatal hippocampal precursor cells. J Biol Chem 2012, 287: 20187-20196.

34. Benarroch EE. Neuropeptide Y: its multiple effects in the CNS and potential clinical significance. Neurology 2009, 72: 1016-1020.

35. Colmers WF, El Bahh B. Neuropeptide Y and epilepsy. Epilepsy Curr 2003, 3: 53-58.

36. Raghanti MA, Conley T, Sudduth J, Erwin JM, Stimpson CD, Hof PR, et al. Neuropeptide Y-immunoreactive neurons in the cerebral cortex of humans and other haplorrhine primates. Am J Primatol 2013, 75: 415-424.

37. Gaspar P, Berger B, Febvret A, Vigny A, Krieger-Poulet M, Borri-Voltattorni C. Tyrosine hydroxylase-immunoreactive neurons in the human cerebral cortex: a novel catecholaminergic group? Neurosci Lett 1987, 80: 257-262.

38. Ikemoto K, Kitahama K, Nishimura A, Jouvet A, Nishi K, Arai R, et al. Tyrosine hydroxylase and aromatic L-amino acid decarboxylase do not coexist in neurons in the human anterior cingulate cortex. Neurosci Lett 1999, 269: 37-40.

39. Benavides-Piccione R, DeFelipe J. Distribution of neurons expressing tyrosine hydroxylase in the human cerebral cortex. J Anat 2007, 211: 212-222.

40. Wyeth MS, Zhang N, Mody I, Houser CR. Selective reduction of cholecystokinin-positive basket cell innervation in a model of temporal lobe epilepsy. J Neurosci 2010, 30: 8993-9006.

41. Morozov YM, Freund TF. Postnatal development and migration of cholecystokinin-immunoreactive interneurons in rat hippocampus. Neuroscience 2003, 120: 923-939.

42. Pawelzik H, Hughes DI, Thomson AM. Physiological and morphological diversity of immunocytochemically defined parvalbumin- and cholecystokinin-positive interneurones in CA1 of the adult rat hippocampus. J Comp Neurol 2002, 443: 346-367.

43. Sun C, Sun J, Erisir A, Kapur J. Loss of cholecystokinincontaining terminals in temporal lobe epilepsy. Neurobiol Dis 2014, 62: 44-55.

44. Najm IM, Sarnat HB, Blumcke I. Review: The international consensus classification of Focal Cortical Dysplasia - a critical update 2018. Neuropathol Appl Neurobiol 2018, 44: 18-31.

45. Mullen RJ, Buck CR, Smith AM. NeuN, a neuronal specific nuclear protein in vertebrates. Development 1992, 116: 201-211.

46. Wang G, He F, Xu Y, Zhang Y, Wang X, Zhou C, et al. Immunopotentiator thymosin alpha-1 promotes neurogenesis and 
cognition in the developing mouse via a systemic Th1 bias. Neurosci Bull 2017, 33: 675-684.

47. Tansey KE, Hill MJ. Enrichment of schizophrenia heritability in both neuronal and glia cell regulatory elements. Transl Psychiatry 2018, 8: 7.

48. DeFelipe J. Anatomical and molecular heterogeneity of cortical gabaergic interneurons. In: Grillner S, Graybiel AM (Eds.). Microcircuits: The Interface Between Neurons And Global Brain Function. Cambridge, MA: The MIT Press, 2006.

49. Karagiannis A, Gallopin T, David C, Battaglia D, Geoffroy H, Rossier J, et al. Classification of NPY-expressing neocortical interneurons. J Neurosci 2009, 29: 3642-3659.

50. Kawaguchi Y, Kubota Y. GABAergic cell subtypes and their synaptic connections in rat frontal cortex. Cereb Cortex 1997, 7: 476-486.

51. Hendry SH, Jones EG, Emson PC. Morphology, distribution, and synaptic relations of somatostatin- and neuropeptide Y-immunoreactive neurons in rat and monkey neocortex. J Neurosci 1984, 4: 2497-2517.

52. Sherwood CC, Raghanti MA, Stimpson CD, Spocter MA, Uddin $\mathrm{M}$, Boddy $\mathrm{AM}$, et al. Inhibitory interneurons of the human prefrontal cortex display conserved evolution of the phenotype and related genes. Proc Biol Sci 2010, 277: 1011-1020.

53. Wittner L, Eross L, Czirjak S, Halasz P, Freund TF, Magloczky Z. Surviving CA1 pyramidal cells receive intact perisomatic inhibitory input in the human epileptic hippocampus. Brain 2005, 128: $138-152$.
54. Thom M, Martinian L, Parnavelas JG, Sisodiya SM. Distribution of cortical interneurons in grey matter heterotopia in patients with epilepsy. Epilepsia 2004, 45: 916-923.

55. Beaulieu C. Numerical data on neocortical neurons in adult rat, with special reference to the GABA population. Brain Res 1993, 609: 284-292.

56. DeFelipe J. Chandelier cells and epilepsy. Brain 1999, $122(\mathrm{Pt}$ 10): 1807-1822.

57. Medici V, Rossini L, Deleo F, Tringali G, Tassi L, Cardinale F, et al. Different parvalbumin and GABA expression in human epileptogenic focal cortical dysplasia. Epilepsia 2016, 57: 1109-1119.

58. Kubota Y, Hattori R, Yui Y. Three distinct subpopulations of GABAergic neurons in rat frontal agranular cortex. Brain Res 1994, 649: 159-173.

59. Kuljis RO, Rakic P. Distribution of neuropeptide Y-containing perikarya and axons in various neocortical areas in the macaque monkey. J Comp Neurol 1989, 280: 383-392.

60. Benavides-Piccione R, DeFelipe J. Different populations of tyrosine-hydroxylase-immunoreactive neurons defined by differential expression of nitric oxide synthase in the human temporal cortex. Cereb Cortex 2003, 13: 297-307.

61. Zhang LX, Smith MA, Kim SY, Rosen JB, Weiss SR, Post RM. Changes in cholecystokinin mRNA expression after amygdala kindled seizures: an in situ hybridization study. Brain Res Mol Brain Res 1996, 35: 278-284. 